source of strength and guidance to many boys who were perforce separated from their parents. During these war years he also worked as a member of an ambulance team in Somerset and helped with the formation of an Air Training Corps Flight in the school in 1941. His other great interest was music and he was, for 21 years until his death, a very active and devoted member of his local church and a constant performer with the Royal Choral Society.

For many years until his death he was a chief examiner in Mathematics for the Northern Universities Joint Matriculation Board. A life member of the Mathematical Association, he attended regularly at the Annual Conferences as treasurer and member of the Diploma Board and as a member of the Council, thus contributing much in time and experience to the Association. For some years he was the energetic secretary of the London Branch and then its chairman, and during this period he organised several successful meetings in London. He became a member of the Institute of Mathematics and its Applications on its formation.

I first met him when he joined Highbury School, and over the years our friendship grew and matured. He was an ever-cheerful and loyal companion, never ruffled, completely reliable and unsparing of himself in his efforts to promote and enlarge the activities of any organisation with which he was connected. He was a tireless worker and his example of service is one to be emulated; he will be sadly missed for many a long day, not only by the family whom he adored, but by his many friends and all who knew him.

B. J. F. DORRINGTON

\title{
Vincenzo Consolato Antonino Ferraro
}

Professor V. C. A. Ferraro died unexpectedly on January 4, 1974 at the age of 66 while he was Professor of Mathematics at Queen Mary College, London. Members of the Mathematical Association will remember that he was its President for the year 1962/63. His research work in hydromagnetics and solar-terrestrial relationships and his interests in the arts have been described elsewhere; this brief notice concerns his views on the teaching of mathematics.

Ferraro, as his research work would lead one to expect, stressed the importance of the teaching of electromagnetics. But he attached equal importance to instruction in classical mechanics. In his student days between the wars, this subject had come to be under-estimated in competition with the fashionable topics of quantum mechanics and relativity. Experience showed him, as it did to other applied mathematicians, that this was an error, as one example among many will show. The present-day exploration of the solar system by spacecraft necessitates a thorough knowledge of classical mechanics and of Newtonian gravitation, without which the orbits of these vehicles cannot be calculated. 
In those far-off days of the 1930s when Ferraro and I were colleagues at King's College, London, vector methods were being introduced into the teaching of applied mathematics in London. I well remember how strongly he supported the new technique, which has since come into general use. Ferraro's experience as a research worker also led him to emphasise the importance of manipulative skill in applied mathematics. He stressed it throughout his teaching life at the university level, but he also urged its importance on any one who could influence the teaching of mathematics at the secondary school level. He was himself an accomplished and lucid lecturer and, as he could speak Italian as well as English, he was much sought after as a lecturer at summer schools in Italy. The only criticism, if it is one, of his lectures which I have heard is that they were perhaps too perfect. A student who took careful notes came away with the impression that the subject was exhausted and that no further reading was necessary. There are few university teachers of whom this can be said.

I am indebted to Dr. C. Plumpton of Queen Mary College for supplying part of the information on which this notice is based.

G. C. McVITTIE

\section{Classroom notes}

\section{Food for thought}

\section{A postscript to Note 298 (The seven-colour map)}

To make a torus exhibiting the 7-colour map, take $\frac{1}{2} \mathrm{lb}$ of self-raising flour, $\frac{1}{2} \mathrm{lb}$ of butter, ... but perhaps I should explain. On the occasion of a visiting speaker coming to talk to the school Mathematical Society (which meets in the evening) about the 4-colour 'theorem' (and its associated results), we consumed with our coffee a cake in this form. My wife baked it, using a sponge-ring tin, and $I$ iced it, in 7 colours, and the result was acclaimed a success in all respects, which no doubt any member whose wife is a good cook should be able to repeat; the mathematical part of the recipe being as follows:

With the usual identifications, the simplest portrayal of the 7-colour map is that of Fig. 1. Cutting this along $P Q$, and uniting the top and bottom edges, we obtain Fig. 2. (By a well-known optical illusion, it is now difficult to believe, but is nevertheless true, that (say) $A B$ does coincide with $C D$ if these edges are brought together again!). Bringing into coincidence the ends of the rectangle by distorting it in the plane we obtain Fig. 3. Now interpreting this as the view from above of a toroidal cake (with a flat bottom), it should be evident how the icing was carried out. The dividing lines (i.e., 